\title{
An evaluation of functional outcome following minimally invasive plate osteosynthesis in fractures of the distal tibia
}

\section{Yeshwanth Subash, Prabhu Manickam S., Ravikrishna R., Priyadarshini S., Gunalan K. Naidu*}

Department of Orthopaedics, Saveetha Medical College and Hospital, Thandalam, Chennai, Tamil Nadu, India

Received: 20 September 2017

Accepted: 09 October 2017

\section{*Correspondence:}

Dr. Gunalan K. Naidu,

E-mail: gunalan99@yahoo.com

Copyright: (C) the author(s), publisher and licensee Medip Academy. This is an open-access article distributed under the terms of the Creative Commons Attribution Non-Commercial License, which permits unrestricted non-commercial use, distribution, and reproduction in any medium, provided the original work is properly cited.

\begin{abstract}
Background: Management of fractures of the distal tibia remains a challenging proposition due to the fact that the major part of the bone is in a subcutaneous location and the blood supply is quite precarious. Conventional forms of osteosynthesis are associated with high rates of infection and nonunion. Due to extensive soft tissue stripping, the vascularity is compromised and often results in poor wound healing and tends to compromise fracture healing as well. Closed reduction with minimally invasive plate osteosynthesis (MIPO) addresses these issues and has emerged as a viable treatment option with minimal complications. The aim of this study was to assess the functional outcome MIPO using locking compression plates (LCP).

Methods: 32 patients with distal tibial fractures treated by MIPO technique with LCP fixation were studied from January 2012 to January 2014 and were followed up for a period of 2 years.

Results: All the fractures in our series united well at the end of 6 months with mean time to radiological evidence of callus formation at 10 weeks and the mean time to fracture union was 20 weeks. There were 2 cases with varus angulation in our series and no cases with implant failure. There were 3 patients with superficial skin infections and no cases of deep infection.

Conclusions: We conclude that MIPO with LCP is an effective treatment option for distal tibial fractures avoiding all the complications associated with other forms of internal fixation. We strongly recommend its usage in these types of complex injuries.
\end{abstract}

Keywords: Distal tibia, MIPO, LCP, Osteosynthesis

\section{INTRODUCTION}

Fractures of the distal tibia are complex injuries which remain a challenging proposition for treating Orthopaedic surgeon. These fractures are caused by high energy axial compressive, direct bending or rotational forces. The primary aim of management in these type of fractures are to restore the normal mechanical axis with accurate reduction without valgus or varus angulation, ensure stability of the ankle joint and to restore a good range of movement. Non operative management is often not feasible in these type of fractures due to the prolonged period of immobilization required and the high rates of morbidity in the form of joint stiffness in $40 \%$ of the cases as well as shortening and rotational deformities. ${ }^{1,2}$

Open anatomic reduction was once the standard procedure for plate osteosynthesis in the early sixties and seventies. $^{3}$ Open reduction and internal fixation procedures require the use of long incisions which involve extensive soft tissue dissection and stripping of the periosteum. This compromises the vascularity of the bone resulting in high rates of complications like infection and delayed or nonunion. ${ }^{4-7}$ In compound fractures various types of external fixators can be applied but these fixators have a poor patient compliance and also 
associated with issues such as pintract infection, nonunion and malunion. 8

Interlocking intramedullary nailing has been described as a good option for treating distal tibial fractures as advocated by a few authors in their studies. But it is generally considered unsuitable due to technical difficulties and design limitations. ${ }^{10}$

With the advent of locking compression plates, MIPO has become a good viable option for the management of both intra and extra articular fractures of the distal tibia. Through small skin incisions placed proximal and distal to the fracture site. The plate is slid extraperiosteally and fixed with locking screws. The plate in this situation acts like a bridging external fixator. This has the advantages of preserving the blood supply as well as the fracture heamatoma with minimal soft tissue dissection which results in good secondary bone healing. ${ }^{11-17}$ Since the screw heads lock on to the plate, the LCP provides excellent stability as compared to a conventional plate and also protects against loss of fracture reduction. This technique has been used successfully in the management of these fractures and the results have been quite promising. ${ }^{14,18}$

\section{METHODS}

32 patients with fractures of the distal tibia treated using Locking compression plate with MIPO technique were included in the study. This was a prospective study done at Saveetha medical college and hospital from January 2012 to January 2014. All patients with distal tibial fractures aged more than 18 years with or without intra articular extension and Grade 1 Gustilo and Anderson compound fractures were included in our study. Skeletally immature patients, grade 2 and 3 Gustilo and Anderson fractures and pathological fractures were excluded from the study. AO/OTA system was used to classify the fractures. ${ }^{19}$ At the time of admission, the affected limb was stabilized with an above knee plaster and the patient was clinically and radiologically evaluated. The limb was elevated and appropriate analgesics were administered. The patients were taken up for surgery as early as possible depending on their medical fitness for surgery. There was delay in operating a few cases because of gross edema of the affected limb.

The procedure was done under regional anaesthesia with tourniquet control. One dose of intravenous antibiotics was given at the time of induction of anaesthesia and was continued till the third postoperative day followed by five days of oral antibiotics. The patient was placed on a radiolucent table and prepping and draping was done in the routine manner. A $3 \mathrm{~cm}$ curved longitudional incision was made overlying the medial malleolus taking care to protect the saphenous vein and nerve. A $2 \mathrm{~cm}$ incision was then made proximal to the fracture site. An extra periosteal subcutaneous tunnel was made between these two incisions and a $4.5 \mathrm{~mm}$ precontoured LCP was passed in a retrograde fashion under fluoroscopic guidance. In our series we used long plates due to the fact that increasing the length of the plate increases the strength of the fracture construct. ${ }^{20}$ The fracture was then reduced by indirect method by giving manual traction. In a few cases a calcaneal Steinmann pin was used for reduction and a pointed reduction forceps was also used to aid reduction at the fracture site. A minimum of 3 locking screws were placed proximal and distal to the fracture site. We did not encounter a necessity to use a lag screw across the fracture site in any of our cases.

In 8 of the 14 patients who had associated lateral malleolus fractures, fixation was done using a $3.5 \mathrm{~mm}$ reconstruction plate. After ensuring haemostasis and giving a thorough wound wash, closure was done in layers sterile dressings were applied. In the postoperative period the limb was kept elevated and dressings were done at regular intervals. Suture removal was done on the $12^{\text {th }}$ postoperative day. Active ankle and knee movements were encouraged from the first postoperative day itself as per the pain tolerance and compliance of the patient. Patients were mobilized with strict non weight bearing walking with either axillary crutches or walking frames based on the age of the patient. Non weight bearing walking was advocated for a minimum period of 12 weeks or until radiological and clinical evidence of complete union of the fracture. Following discharge clinical and radiological evaluations were done at 6 weeks and at 3, 6, 9, 12 and 24 months. The fracture was considered united when a visible bridging callus was seen in one cortex on both antero posterior and lateral $\mathrm{x}$ rays and the patient able to do full weight weight bearing without pain. ${ }^{22}$ All patients were evaluated using American Orthopaedic Foot and Ankle Society Score (AOFAS).

\section{RESULTS}

In this study 32 patients with distal tibial fractures were treated by LCP fixation using MIPO technique. There were 24 male and 8 female patients (Figure 1). Right sided fractures were more common with 19 patients while 13 had fractures of the left tibia (Figure 2). The age of the patients ranged from 20 to 58 years with the mean age being 45 years (Table 1 ).

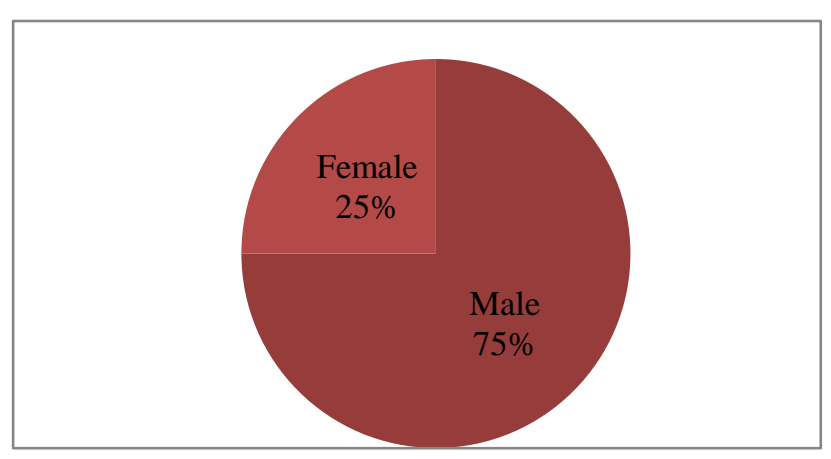

Figure 1: Sex incidence. 


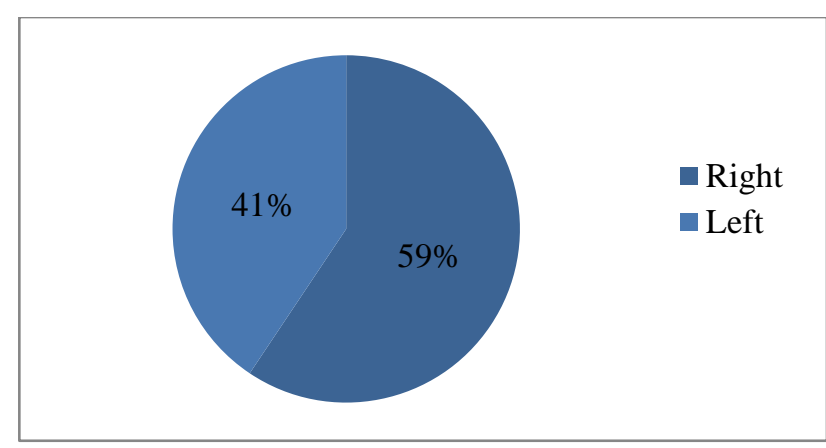

Figure 2: Side dominance.

Table 1: Showing age of patients.

\begin{tabular}{|llll|}
\hline S.no. & $\begin{array}{l}\text { Age in } \\
\text { years }\end{array}$ & $\begin{array}{l}\text { Number of } \\
\text { patients }\end{array}$ & $\begin{array}{l}\text { Percentage } \\
(\%)\end{array}$ \\
\hline $\mathbf{1}$ & $21-30$ & 12 & 37.5 \\
\hline $\mathbf{2}$ & $31-40$ & 10 & 31.26 \\
\hline $\mathbf{3}$ & $41-50$ & 7 & 21.87 \\
\hline $\mathbf{4}$ & $51-60$ & 3 & 9.37 \\
\hline
\end{tabular}

28 cases had closed fractures while 4 patients had a grade 1 Gustilo and Anderson compound fracture. The most common mode of injury was road traffic accidents as seen in 26 patients (Figure 3). Associated injuries were seen in 19 patients with 14 patients having a fracture of the lateral malleolus for which 8 of them underwent fixation with $3.5 \mathrm{~mm}$ reconstruction plates (Table 2).

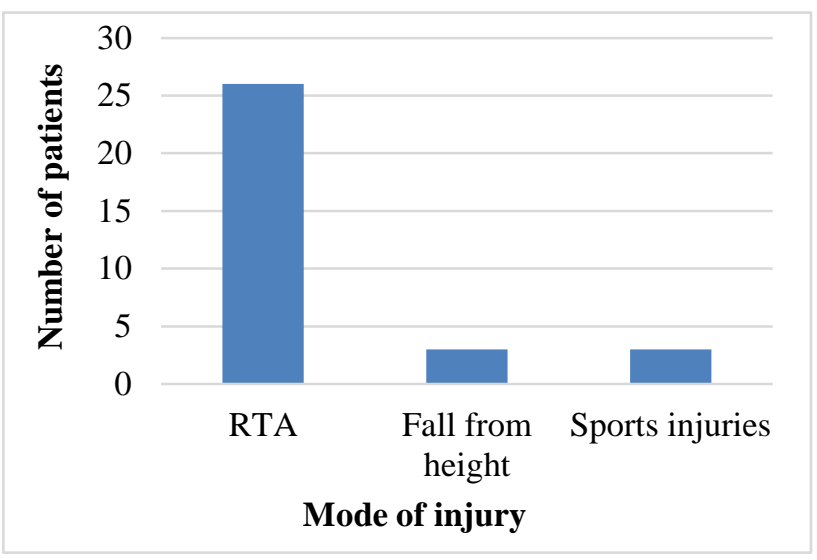

Figure 3: Mode of injury.

Table 2: Associated fractures.

\begin{tabular}{|llll|}
\hline \hline S.no. & $\begin{array}{l}\text { Associated } \\
\text { fractures }\end{array}$ & $\begin{array}{l}\text { Number of } \\
\text { patients }\end{array}$ & $\begin{array}{l}\text { Percentage } \\
(\%)\end{array}$ \\
\hline $\mathbf{1}$ & Clavicle & 2 & 6.25 \\
\hline $\mathbf{2}$ & Distal radius & 3 & 9.37 \\
\hline $\mathbf{3}$ & Fibula & 14 & 43.75 \\
\hline
\end{tabular}

Most of the patients in our study presented to the hospital within 24 hours of injury while two cases presented after 24 hours (Table 3 ).
Table 3: Time of presentation to the hospital.

\begin{tabular}{|llll|}
\hline S.no. & $\begin{array}{l}\text { Time of } \\
\text { presentation in } \\
\text { hours }\end{array}$ & $\begin{array}{l}\text { Number of } \\
\text { patients }\end{array}$ & $\begin{array}{l}\text { Percentage } \\
(\%)\end{array}$ \\
\hline $\mathbf{1}$ & $<24$ & 12 & 37.5 \\
\hline $\mathbf{2}$ & $24-48$ & 7 & 21.87 \\
\hline $\mathbf{3}$ & $48-72$ & 10 & 31.25 \\
\hline $\mathbf{4}$ & $>72$ & 2 & 6.25 \\
\hline
\end{tabular}

The reason for the late presentation was delay in case referral from another center and one patient had initially opted for native treatment and then reported later to the hospital for further management. Most of the patients were operated within 1 to 3 days of presentation to the hospital while 2 patients were operated within 24 hours (Table 4). The fractures were classified according to the AO/OTA classification and OT43-A1 was the most common fracture type seen in our study (Table 5).

Table 4: Time from presentation to surgery.

\begin{tabular}{|clll|}
\hline S.no. & Time frame & $\begin{array}{l}\text { Number of } \\
\text { patients }\end{array}$ & $\begin{array}{l}\text { Percentage } \\
(\%)\end{array}$ \\
\hline $\mathbf{1}$ & $<24$ hours & 2 & 6.25 \\
\hline $\mathbf{2}$ & $1-3$ days & 17 & 53.2 \\
\hline $\mathbf{3}$ & $3-5$ days & 9 & 28.12 \\
\hline $\mathbf{4}$ & $>5$ days & 4 & 12.5 \\
\hline
\end{tabular}

Table 5: Type of fracture according to OTA classification.

\begin{tabular}{|llll|}
\hline S.no. & OTA type & $\begin{array}{l}\text { Number of } \\
\text { patients }\end{array}$ & $\begin{array}{l}\text { Percentage } \\
(\%)\end{array}$ \\
\hline $\mathbf{1}$ & 43-A1 & 24 & 75 \\
\hline $\mathbf{2}$ & 43-A2 & 4 & 12.5 \\
\hline $\mathbf{3}$ & $43-\mathrm{A} 3$ & 2 & 6.25 \\
\hline $\mathbf{4}$ & $43-\mathrm{B} 1$ & 2 & 6.25 \\
\hline
\end{tabular}

Table 6: Duration of surgery.

\begin{tabular}{|llll|}
\hline S.no. & $\begin{array}{l}\text { Time in } \\
\text { minutes }\end{array}$ & $\begin{array}{l}\text { Number of } \\
\text { patients }\end{array}$ & $\begin{array}{l}\text { Percentage } \\
(\%)\end{array}$ \\
\hline $\mathbf{1}$ & $31-40$ & 14 & 43.75 \\
\hline $\mathbf{2}$ & $41-50$ & 10 & 31.25 \\
\hline $\mathbf{3}$ & $51-60$ & 5 & 15.62 \\
\hline $\mathbf{4}$ & $61-70$ & 3 & 9.37 \\
\hline
\end{tabular}

The operating time period ranged from 32 to 70 minutes with the average surgical time being 45 minutes (Table 6 ). The average period of stay in the hospital was 10 days ranging from 8 to 14 days. The mean time to radiological time to callus formation was 10 weeks ranging from 8 to 15 weeks. $68 \%$ of the patients had radiological evidence of callus formation by 8 weeks and all of them had evidence at the end of 6 months. The mean time to 
achieve clinical and radiological union was 20 weeks with a range from 17 to 30 weeks.

Table 7: Complications.

\begin{tabular}{|c|c|c|}
\hline Complications & $\begin{array}{l}\text { Number of } \\
\text { patients }\end{array}$ & $\begin{array}{l}\text { Percentage } \\
(\%)\end{array}$ \\
\hline $\begin{array}{l}\text { Superficial skin } \\
\text { infection }\end{array}$ & 3 & 9.37 \\
\hline Deep skin infection & 0 & 0 \\
\hline \multicolumn{3}{|c|}{ Ankle movement restriction } \\
\hline$>75 \%$ & 0 & 0 \\
\hline $50-75 \%$ & 0 & 0 \\
\hline $25-50 \%$ & 2 & 6.25 \\
\hline$<25 \%$ & 1 & 3.12 \\
\hline Varus angulation & 1 & 3.12 \\
\hline Implant failure & 0 & 0 \\
\hline
\end{tabular}

The mean time to full weight bearing walking was 14 weeks ranging from 12 to 24 weeks. There were no cases of nonunion our series and no cases of implant failure. Superficial skin infection was seen in three patients which settled down well with antibiotics while 3 patients had restriction of ankle movements and 1 patient had a varus malunion (Table 7). Based on the IOFAS score 18 patients had excellent results while good results were seen in 12 patients and 3 patients had a fair result (Table 8). The limitations of our study could possibly be a relatively small sample of patients and a short period of follow up.

Table 8: Results according to AOFAS score.

\begin{tabular}{|lll|}
\hline AOFAS score & $\begin{array}{l}\text { Number of } \\
\text { patients }\end{array}$ & $\begin{array}{l}\text { Percentage } \\
(\%)\end{array}$ \\
\hline Excellent & 18 & 56.25 \\
\hline Good & 12 & 37.5 \\
\hline Fair & 2 & 6.25 \\
\hline
\end{tabular}

\section{DISCUSSION}

Fractures of the distal tibia are difficult injuries to manage and the factors like severity of the initial injury, amount of fracture comminution and damage to the articular surface of the ankle has a direct bearing on the functional outcome. Various modalities of treatment have been advocated in the management of these fractures like open reduction and internal fixation, external fixation and interlocking intramedullary nailing. External fixators used in compound fractures have been associated with a high rate of complications such as pin tract infection, loss of reduction, nonunion and malunion. ${ }^{8,9}$ Intramedullary fixation with nails have the advantage of providing a closed stabilization without disturbing the fracture haematoma and also prevents damage to the underlying soft tissues. ${ }^{15}$ However due to the fact that the medullary cavity widens at the region of the metaphysis the interlocking nail does not seem to provide the angular and rotational stability required and results in complications like loss of fracture reduction and failure of the implant. High rates of malunion have been reported due to the above factors. ${ }^{24}$

Open reduction and internal fixation with compression plates has its disadvantages as well. Borelli et al have demonstrated that the distal third of tibia has a relatively rich extraosseus blood supply which is primarily provided by branches of the anterior and posterior tibial arteries. $^{25}$ Due to this fact they have demonstrated that open plating procedures produce a higher amount of disruption of the blood supply as compared to a minimally invasive technique. Distal tibial fractures are often associated with poor wound healing due to the gross limb edema following injury. So in cases with severe edema limb elevation was done and the surgery was deferred till the swelling had subsided. Surgery was performed between the $3^{\text {rd }}$ and $5^{\text {th }}$ days in 9 of the patients in our study due this reason. We observed that there were no differences in union rate and complications in those patients who were operated on different time periods.

Gao et al reported more wound complications in the LCP group (14.6\%) as compared to the nailing group $(6.8 \%){ }^{26}$ Average rates of infection in various studies available was between 5 to $15 \%$. In our study superficial skin infections were seen in 3 patients $(9.37 \%)$. There were no patients with deep infection. The rate of malunions reported in literature varies from 0 to $5 \%$ while delayed and nonunions have been reported to range from 5 to $16 \%$. There were no non unions in our study. All fractures united well at the end of 6 month. All 32 patients were followed up for a period of 2 years. No patients were lost to follow up in our series. There was 1 case of varus malunion in our study but that patient had a good functional outcome and hence no further intervention was necessary at that time. He would probably require a longer period of follow up in order assess the risk of developing arthritis of the ankle joint at a later stage due to the malunion. Injury to the great saphenous nerve and vein can occur rarely. We did not encounter any such injuries in our study. A few of our patients complained of pain over the medial malleolus and slight prominence of the hardware but not causing too much discomfort to the patient. Metal exit was not done as a routine and none of the patients required one at the end of 2 years follow up. One of the observations noted in our study was the fact that using the definition of painless full weight bearing walking together with radiological evidence of callus formation, bone healing with MIPO technique seems prolonged in comparison to open reduction with compression plating and intramedullary interlocking nailing. ${ }^{27}$

\section{CONCLUSION}

Management of fractures of the distal tibia with LCP using MIPO technique offers a reliable and reproducible procedure providing excellent fracture stability while preserving the vascularity to the bone and soft tissues. It 
also avoids the complications associated with other forms of fixation available for these fractures. Even though fracture union appears to be a little prolonged as compared to other procedures, its advantages far outweigh its disadvantages. We would strongly recommend its use in distal tibial fracture management.

Funding: No funding sources

Conflict of interest: None declared

Ethical approval: The study was approved by the institutional ethics committee

\section{REFERENCES}

1. Oni OO, Stafford H, Gregg PJ. A study of diaphyseal fracture repair using tissue isolation techniques. Injury. 1992;23:467-70.

2. Russell TA. Fractures of the tibia and fibula. In: Rockwood CA, Green DP, Buckolz RW, Heckman JD, editors. Fractures in adults. 4th ed. Philadelphia: Lippincott; 1996: 2139-2157.

3. Rüedi TP and Murphy WM. AO Principles of Fracture Management. New York: Thieme Medical Publishers; 2001: 253-255.

4. Fisher WD, Hamblen DL. Problems and pitfalls of results and complications. Injury. 1978;10:99-107.

5. McFerran MA, Smith SW, Boulas HJ, Schwartz HS. Complications encountered in the treatment of pilon fractures. J Orthop Trauma. 1992;6:195-200.

6. Rüedi T. Fractures of the lower end of the tibia into the ankle joint: results 9 years after open reduction and internal fixation. Injury. 1973;5:130-4.

7. Ruedi TP, Allgower M. The operative treatment of intra-articular fractures of the lower end of the tibia. Clin Orthop Relat Res. 1979;138:105-10.

8. Rammelt S, Endres T, Grass R, Zwipp H. The role of external fixation in acute ankle trauma. Foot ankle Clin. 2004;9:455-74.

9. Blauth M, Bastian L, Krettek C, Knop C, Evans S. Surgical options for the treatment of severe tibial pilon fractures: a study of three techniques. J Orthop Trauma. 2001;15:153-60.

10. Robinson CM, McLauchlan GJ, McLean IP, CourtBrown CM. Distal metaphyseal fractures of the tibia with minimal involvement of the ankle. J Bone Joint Surg. 1995;77:781-7.

11. Mafulli N, Toms A, MC Murtle A, Oliva F. Percutaneous plating of distal tibial fractures. Int Orthop. 2004;28:159-62.

12. Redfern DJ, Syed SU, Davies SJM. Fractures of the distal tibia: minimal invasive plate osteosynthesis. Injury. 2004;35:615-20.

13. Hazarika S, Chakravarthy J, Cooper J. Minimally invasive locking plate osteosynthesis for fractures of the distal tibia. Results in 20 patients. Injury. 2006;37(9):877-87.

14. Hasenboehler E, Rikli D, Babst R. Locking compression plate with minimally invasive plate osteosynthesis in diaphyseal and distal tibial fracture: a retrospective study of 32 patients. Injury. 2007;38:365-70.

15. Vallier HA, Le TT, Bedi A. Radiographic and clinical comparisons of distal tibia shaft fractures (4 to $11 \mathrm{~cm}$ proximal to the plafond): plating versus intramedullary nailing. $\mathrm{J}$ Orthop Trauma. 2008;22(5):307-11.

16. Collinge $\mathrm{C}$, Kuper M, Larson K, Protzman R. Minimally Invasive Plating of High- energy Metaphyseal Distal tibial fractures. J Orthop Trauma. 2007;21:355-61.

17. Farouk O, Krettek C, Miclau T, Schandelmaier P, Guy P, Tscherne H. Minimally invasive plate osteosynthesis and vascularity: preliminary results of a cadaver injection study. Injury. 1997;28(1):712.

18. Lawrence M, Mar F, Swanson SAV. Engineering considerations in the internal fixation of fractures. $\mathbf{J}$ Bone Joint Surg. 1969;51B:754-68.

19. Barie DP. Pilon fractures. In: Bucholz RW, CourtBrown CM, Heckman JD, Tornetta P. Rockwood and Green's Fractures in Adults. 7th edition. Philadelphia: Lippincott Williams and Wilkins; 2010: 1928-1974.

20. Sanders R, Haidukewych GJ, Milne T, Dennis J, Latta LL. Minimal versus maximal plate fixation techniques of the ulna: the biomechanical effect of number of screws and plate length. J Orthop Trauma. 2002;16:166-71.

21. Dhakar A, Annappa R, Gupta M, Harshavardhan H, Kotian P, Suresh PK. Minimally invasive plate osteosynthesis using locking plate for distal tibia fractures. J Clin Diagnostic Res. 2016;10(3):1-4.

22. Perren SM, Perren T, Schneider E. Are the terms "biology" and "osteosynthesis" contradictory? Ther Umsch. 2003;60:713-21.

23. Kitaoka HB, Alexander IJ, Adelaar RS, Nunley JA, Myerson MS, Sanders M. Clinical rating system for the ankle, hindfoot, midfoot, hallux and lesser toes. Foot Ankle Int. 1994;15:349-53.

24. Fan CY, Chiang CC, Chuang TY, Chiu FY, Chen TH. Interlocking nails for displaced metaphyseal fractures of the distal tibia. Injury. 2005;36:669-74.

25. Borrelli J, Prickett W, Song E, Becker D, Ricci W. Extra osseous blood supply of the distal tibia and the effects of different plating techniques: Human cadaveric study. J Orthop Trauma. 2002;16:691-5.

26. Gao H, Zhang CO, Luo CF, Zhou ZB, Zeng BF. Fractures of the distal tibia treated with polyaxial locking plating. Clin Orthop Relat Res. 2009;467:831-83.

27. Perren SM. Evolution of the internal fixation of long bone fractures. The scientific basis of biological internal fixation: choosing a new balance between stability and biology. J Bone Joint Surg Br. 2002;84(8):1093-110.

Cite this article as: Subash Y, Prabhu Manickam S, Ravikrishna R, Priyadarshini S, Naidu GK. An evaluation of functional outcome following minimally invasive plate osteosynthesis in fractures of the distal tibia. Int J Res Orthop 2017;3:1136-40. 